\title{
圧縮混合モード荷重下に打けるぜい性材料のき裂進展挙動
}

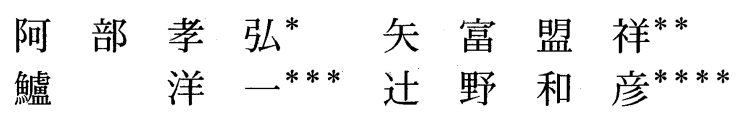

\section{Crack Extension Behavior in the Brittle Material under Compression Mixed Mode Loadings}

\author{
by \\ Takahiro ABE ${ }^{*}$, Chikayoshi YATOMI ${ }^{* *}$, \\ Yoichi Suzuki $^{* * *}$ and Kazuhiko Tsujino ${ }^{* * * *}$
}

The purpose of this paper is to examine the crack extension behavior in the brittle material under the compression mixed mode loadings. We here employ a cement paste as the brittle materials. An initial crack was inserted in the center of the disc-type test-piece. The compressive loads were obliquely applied to the initial crack. The extension phenomena of the crack were photographed by a high-speed video camera, and the image analysis was carried out. Using the result of the image analysis, we observed the crack extension behavior in the experiment in detail. It was confirmed that the cracks first occurred from the tips of the initial crack and the secondary cracks were observed after the first cracks. The experimental results were examined using the energy release rate criterion. As a result, the relations between the fracture load in the experiment and the loading angle were found to agree well with the relations between the energy release rate by the E-integral and the loading angle.

Key words : Crack extension, Mixed mode loading, Image analysis, Energy release rate, E-integral, FEM

\section{1 緒}

\section{言}

土木構造物の主材料であるコンクリートあるいは岩石 などは，ぜい性的な破壊を生じ，その強度を推定するこ とは工学的に重要な問題である.これらの材料は力学的 性質の異なる物質が結合して構成されている非均質な材 料であり，その内部は潜在き裂の存在や構成物質相互の 界面の影響などにより，多数のき裂が干渉し合う非常に 複雑な状況となっている. そのため, 従来の材料力学的 な手法では，対処できなくなり，破壊力学的手法を用い るアプローチが有効と考えられ，多くの研究が精力的に 成されている. Griffith ${ }^{1)}{ }^{2)}$ の破壊理論に始まったき裂進

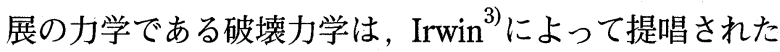
応力拡大係数 $\mathrm{K}$ 值による破壊じん性值の概念へと発展 し，今日ではすでに金属などを主とする工業材料の材料 特性の 1 つとして設計等に用いられている。しかし，そ れらの金属材料では進展き裂が引張荷重により開口して いる場合を対象としたものがほとんどである。それに対 して岩石，コンクリートなどが構造物に使用される場合 には，引張強度が小さいという材料の性質上，ほとんど が圧縮荷重作用下で用いられる。したがって，圧縮荷重 下での強度が問題であり, その圧縮破壊過程のメカニズ ムは引張破壊過程に比べて非常に複雑であることが知ら れている。圧縮荷重下では多くの場合，き裂は閉じて接
\end{abstract}

触し, 荷重状態によっては摩擦力に保持されながら滑り, モード I 型（開き型）とモード II 型（せん断型）の混合 モード状態で折れ曲がって進展する。き裂折れ曲がりの 進展挙動を把握するためには, 破壊パラメーターとして 応力拡大係数よりもエネルギ解放率を用いた方が，モー ド I ，モード II を区別する必要がなく，有利である場合

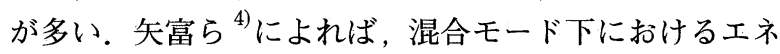
ルギ解放率を求める場合にも, $\mathrm{E}$ 積分 ${ }^{5)}$ が有効であるこ とが報告されている。

そこで，本研究では混合モード下におけるき裂進展挙 動の状況を把握することを目的とし，まず，セメントぺ 一ストで作成した円盤型供試体中に，その直径方向にき 裂を挿入し，き裂面方向から傾斜させた荷重方向で圧縮 実験を行った。その際，き裂の進展状況を高速度ビデオ カメラで撮影し，その映像を基に画像解析を行ない，き 裂進展挙動を観察した。 そして，き裂進展挙動がエネル ギ解放率による破壊規準に従うものとして， E 積分によ る解析結果と実験結果との比較検討を行った.

\section{2 実}

験

\section{$2 \cdot 1$ 実験方法}

実験には，水セメント比を $40 \%$ とした，直径 $10 \mathrm{~cm}$, 厚さ $3 \mathrm{~cm}$ のセメントペーストによる円盤型供試体を作成 し，セメントペースト打ち込み時に，この供試体中央に，

\footnotetext{
$\dagger$ 原稿受理 平成 13 年 7 月 6 日 Received July 6, 2001

* 正 会 員 福井工業高等専門学校環境都市工学科 ₹916-8507 鯖江市下司町, Dept. of Civil Eng., Fukui National College of Tech., Geshicho, Sabae, 916-8507

** 正 会 員 金沢大学工学部土木建設工学科 †920-8667 金沢市小立野, Dept. of Civil Eng., Kanazawa Univ., Kodatsuno, Kanazawa, 920-8667 五大開発(侏)応用工学研究所 T921-8051 金沢市黒田, Applied Mechanics Inst., GODAI Development Corp., Kuroda,Kanazawa, 921-8051

**** 福井工業高等専門学校環境都市工学科 =916-8507 鯖江市下司町, Dept. of Civil Eng., Fukui National College of Tech., Geshi-cho, Sabae, 916-8507
} 
PET（使用済み NTT テレホンカード：平均厚さ 0.275 $\mathrm{mm}$ ）の先端を紙やすりで加工し，切り久をき状にしたも のを埋め込み，脱型時に抜さ取り初期き裂とした。初期 き裂の長さは， $2 \mathrm{~cm}, 3 \mathrm{~cm} の 2$ 種類とした。養生期間は すべて 4 週間とし， $20^{\circ} \mathrm{C}$ 水中養生とした。

Fig. 1 に示すように，この供試体に，き裂面方向に対 して $\beta$ O載荷角度で止縮荷重 $\mathrm{P}$ を作用させ破壊に至るま で負荷実験を行い, 最大荷重值を測定した。載荷角度 $\beta$

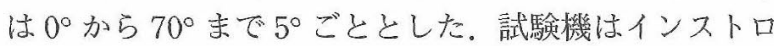
ン社製 5581 型万能試験機を用い，スキャン間隔は 1 秒 であり, 載荷速度 $0.05 \mathrm{~mm} / \mathrm{min}$ の変位制御で載荷した。

\section{$2 \cdot 2$ 実験後の供試体の状況}

実験後の供試体の破壞状況を模式的に措くと Fig. 1 のようであった。 $\beta$ が $5^{\circ} \sim 70^{\circ}$ で破壤した供試体では， 初期き裂先端と載荷点を結ぶ滑らかな曲線を描くき裂と, 載荷点からわずかにずれた位置と初期き裂先端をかなり 湾曲して結ぶき裂を生じた。ここで前者のき裂を1次さ 裂，後者を 2 次き裂と呼ぶことにする。1次き裂の破壊 面の状況は滑らかで㞹物で切ったようにきれいに割れて いたが，2次き裂の破壇面は不規則に割れていて，どれ も回凸が見られた。また，1次き裂は 1 本のみであった が，2次き裂は複数生じている供試体も多く見ら机，載荷 角度によって湾曲の仕方がかり変化していた。このよう な実験結果の報告はこれまでにも多く成されている。

実験後の破壊状沉抢よび実験条件から，まず最初に初 期き裂先端から載荷点に向かって 1 次き裂が発生し，供 試体が1次さ裂によって分割された後に, 載荷点近傍か ら初期き裂先端に向かって 2 次き裂が発生することが予 想されるが, 破堙が載何速度を遅くしても一瞬で生じて しまうため，目視あるいは通常のビデオカメラによる観

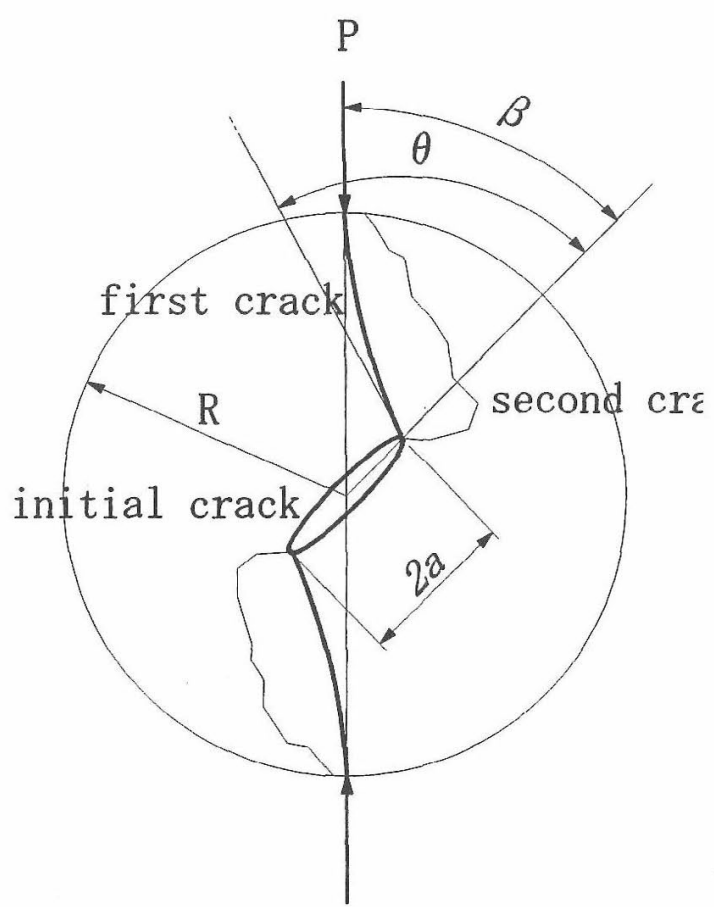

Fig. 1. The test-piece with an initial crack and the pattern of crack extension after the experiment.
察では判別不可能である。

そこで，高速度ビデオカメラ（Kodak EKTAPRO HiSpec Motion Analyzer）を用いて，き裂の進展する瞬間 時を撮影し，只の映像を画像解析することにより，初期 き裂先端から1次き裂が先に発生し，その後載荷面近傍 より 2 次き裂が発生していることを確認した。これにつ いての詳細は第る章にて後述する。

このように高速ビデオ映像により初期き裂先端より 1 次き裂が最初に進展することが明らかとなったことによ り，Fig，1に示すように，初期き裂先端から 1 次き裂が 進展する瞬閒の角度 $\theta$ を供試体表面上で測定した。

\section{3・1 データ処理の手順}

\section{3 き裂進展の画像解析}

撮影に使用した高速度ビデオカメラの，画像レートは 最高 6000 フレーム/秒, 有效画素数は $232 \times 192$ ピク セル，スペクトル感度は $400 \sim 1000 \mathrm{~nm}$ である. 有効画 素数が $232 \times 192$ ピクセルであることから，撮影可能な 領域が限定されるため, 撮影範国は初期き裂から載荷点 までの長方形とし，4000 フレーム/秒で撮影した。この 映像を MPEG 形式の動画として取り込み，1 フレーム／ 秒としたアニメーション GIF として出力する。この GIF 形式の画像から，き裂発生前後の連続した 10 フレーム 程度の画像を個々の画像に分解し，1 フレームごとの画 像を得る。以上の一連の操作を行なうことによって, 初 期き裂が進展する瞬間前後の1/4000 秒間隔の画像(原 画像）定得たことになる。Fig. 2 にこのようにして取り 出した原画像の一例を示す。

1 フレームごとの原画像に，4階調化処理，エッジ抽 出处埋，差画像处埋をそれ学れ実施し，处理をした画像 から破壤時におけるき裂の進展状況を覾測した。画像処 理方法心概略を以下に示す。

3・1・14 階調化処理 画像にはピクセルごとに0〜 255 までの 256 階調の輝度值（以下, Digital Number： DN と略記する。）がある。刘象とする原画像は，簡単に 分肪るとコンタリートとき裂の二種類の DN に分類でき ることが予測される。したがって，き裂部分の DN が決 定できれば，二值化処理によって，き裂部分を抽出する ことができる。しかし，原原画像の DNのヒストグラム

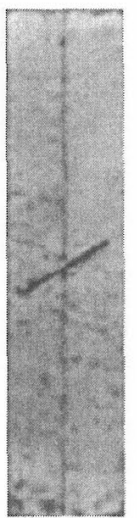

(1)

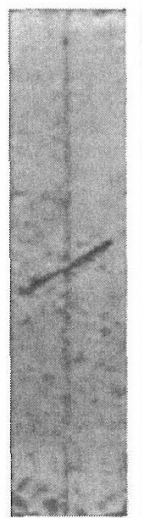

(2)

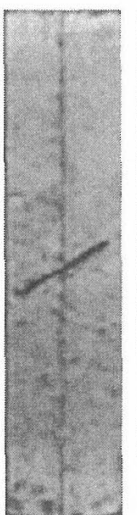

(3)

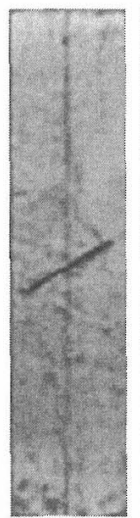

(4)

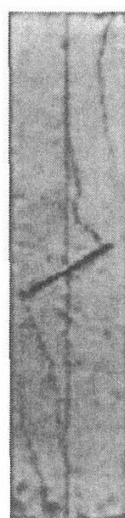

(5)
Fig. 2. Original images. 
を確認したとこう，照明むら，供試体表面の色むらなど の要因によって，只机资れの DN が画像全体で一定して いないことがわかった。㿝こで，き裂部分の DNを目視 により判断し，3つの任意のしきい值を設定した。デー タにより画像全体の明暗の差が大きいため，3つの任意 のしきい值は：定にすることはできなかった。このよう な手法によって得ら机た 4 階調化画像を Fig. 3 に示す。

$3 \cdot 1 \cdot 2$ エッジ抽出処理 DNの特徴が似ている部分 を1つの領域とすると，それらの境界ではDNが急激に 変化している。この境界をエッジというが，き裂部分で はDN が急激に変化していることが予想される。したが って，エッジを抽出することによってき裂部分を取り出 すことができると考えられる。エッジ抽出画像では，4階 調化画像よりも急激にDN の変化があるものを抽出して いることになる。エッジ抽出には，グラディエント処理 とラプラシアン処理が代表的であるが, グラディエント では,座標（x，y）におけるDNの勾配を表す值を大きさ と方向を持つベクトル量として表現され，ラプラシアン では，輪郭の強さだけを抽出する。Fig. 4 にラプラシア ン処理をしたエッジ抽出処理画像を示す。

$3 \cdot 1 \cdot 3$ 差画像 原画像は, き裂進展瞬間前後の 1/4000 秒間隔の画像であり，これらの画像のサイズは全 て等しい。したがって，それぞれの画像の，DNの差を

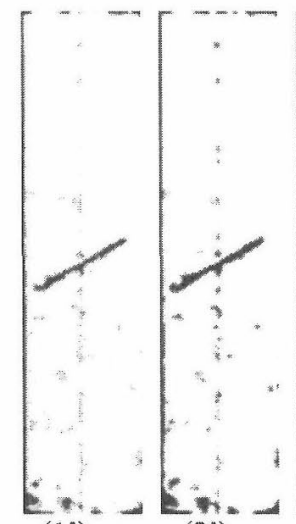

(1')
(2')

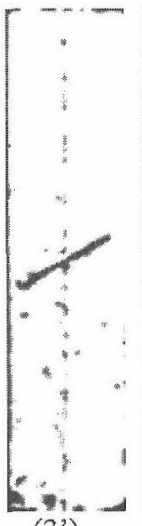

(3')

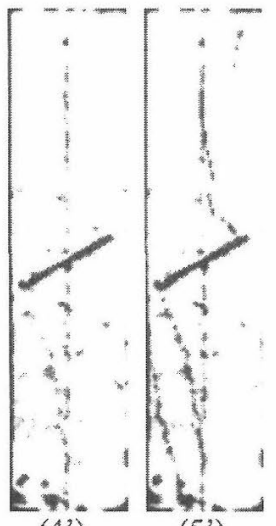

$\left(4^{\prime}\right)$ $\left(5^{\prime}\right)$
Fig. 3. Slice images with the 4stair-stepped level.

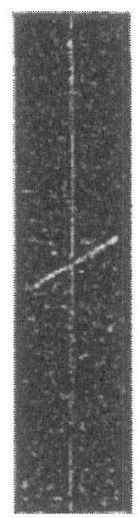

$\left(1{ }^{\prime \prime}\right)$

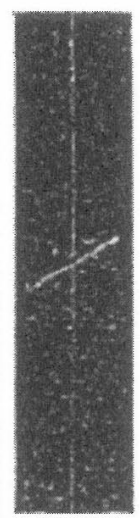

(2')

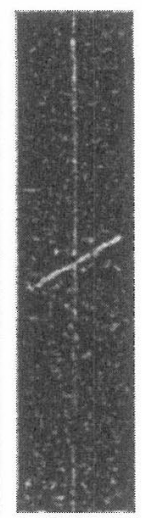

(3')

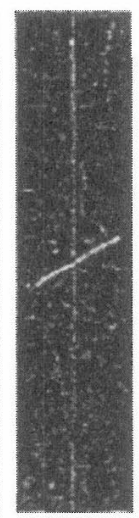

$\left(4^{\prime \prime}\right)$

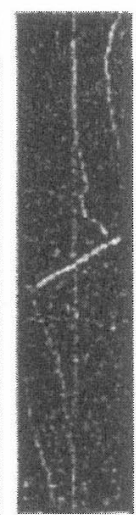

$\left(5^{\prime \prime}\right)$
Fig. 4. Edge enhancement images.
とった差画像が得られる。差画像には規準となる画像と 比較する画像の異なる部分が抽出される。2つの画像で さ裂が進展している部分だけが抽出されることになる。

Fig. 5 にFig. 2 (a)である原画像の 1 枚目を規準画像とし た差画像 I を，Fig. 6 に 1 前の原画像を規準画像とし た差画像 IIを示す。

\section{$3 \cdot 2$ 画像解析の結果と考察}

原画像 Fig. 2 では，き裂の進展は 4，5 コマ目に現れ ているものの，画像全体のコントラストが低く，色のば らつきがあるためにき裂幅が小さい 3 コマ目では，はっ きりとき裂を把握できない４階調化画像 Fig. 3 ではし きい值を 3 つ指定しているため，目標とするき裂以外の ものも抽出されている。これは，き裂部分に類似した DNの部分の影響が出ていると考えられる４，5コマ目 では初期き裂から生じている1次き裂と，その次に発生 している 2 次き裂が抽出できている。しかし，き裂は断 片的に抽出されている。これは，設定したしきい值と実 際のDN が適合していなかったことによると考光られる。 画像によりき裂部分の濃度が濃くなっているが，これは き裂幅が広がっていることを示し，このことより，き裂 はその進展と同時に広がっていることが確認できる。工 ッジ抽出画像 Fig. 4 では，4階調化画像よりも急激に DNの変化があるものを抽出している。き裂は連続的に 抽出されており，4階調化画像では抽出されていない部

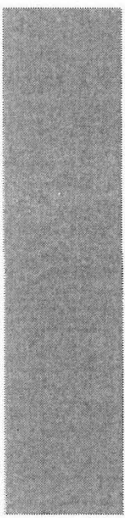

(2)-(1)

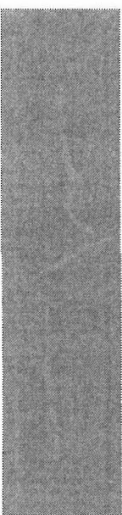

(3)-(1)

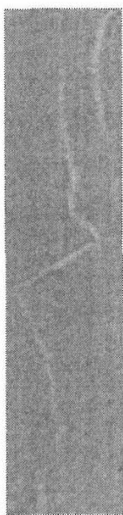

(4)-(1)

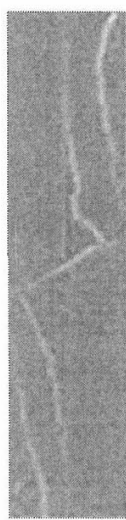

$(5)-(1)$
Fig. 5. Difference images $I$

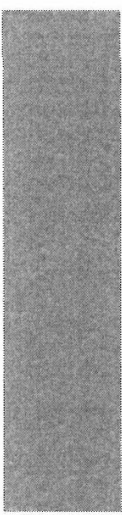

(2)-(1)

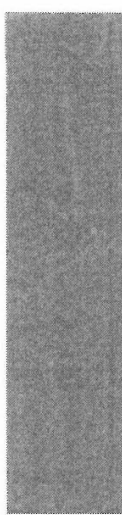

(3)-(2)

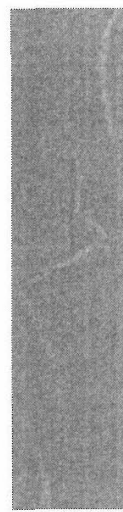

(4)-(3)

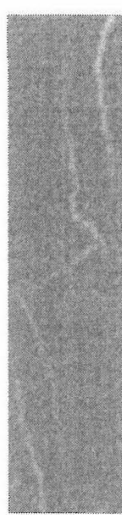

(5)-(4)
Fig. 6. Difference images II. 
分も抽出されている．また，表面に現れているき裂以外 で抽出されている部分は，供試体表面の微細な凹凸具合 によりき裂以外のものもエッジとして抽出されている。 き裂は，4階調化画像と同様に初期き裂から伸びている 1 次き裂と，その後に発生する 2 次き裂が抽出されてい る. 4 階調化画像, エッジ処理画像ともに原画像から得 られる情報以上のものが得られているとは言いがたい．

これらに対して, 差画像 Fig. 5(3)〜 (1) および Fig. 6 (3)〜(2)からは 3 コマ目に 1 次き裂が発生し，4 コマ目 に 2 次き裂が発生していることが明膫に確認できる。き 裂幅の大きさの差が大きければ差画像にはっきりと抽出 できている. Fig. 5 の方が基準をすべて 1 コマ目にとっ ているため差が大きくはっきりと現れている，差画像を 見ることによって, き裂の進展状況を明瞭に確認するこ とが可能であることが明らかとなった。しかし, 差画像 はき裂が進展していなければ，き裂部分を抽出すること はできない，進展がないき裂の状況を把握するためには， しきい值処理，エッジ処理を組み合わせた解析手法を試 みる必要がある。

\section{4 エネルギ解放率を求めるための $\mathrm{E}$ 積分公式}

前章で明らかなように, 最初に初期き裂先端から 1 次 き裂が折れ曲がり進展することが確認できた。 そこで， 初期き裂先端が折れ曲がり進展する瞬間時のエネルギ解 放率を求めることにする。矢富ら ${ }^{4)}$ は圧縮荷重が作用し， き裂面に摩擦および滑りを伴う混合モード下のき裂進展 においては，き裂面上の積分を考虑した補ひずみエネル ギ型 $\mathrm{E}$ 積分を用い机は，進展き裂先端のエネルギ解放率 を精度よく求められること報告している。 な扤，周知の $\mathrm{J}$ 積分では，き裂が直進する瞬間時のエネルギ解放率は 求めることが出来るが, 折机曲がり瞬間時のエネルギ解 放率は求める事が困難であることに注意する.

線形超弾性体の場合で, 変形が微小の場合に限定され た場合では, 外荷重が比例負荷で与えられると, 補ひず みエネルギ型 $\mathrm{E}$ 積分公式は，次式で与えられる.

$$
\begin{aligned}
E(l)=\frac{\partial}{\partial l} & \left\{\int_{\Gamma \cap C^{ \pm}}\left(\frac{1}{2} s \cdot u\right) d s\right\} \\
& -\int_{\Gamma \cap c^{ \pm}}\left(\frac{\partial s}{\partial l} \cdot u\right) d s
\end{aligned}
$$

ここで, $l$ はき裂長さであり, $\partial / \partial l$ は右微分係数である.

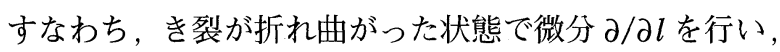
その後, き裂折れ曲がり部分の長さ 0 に収束させた微分 係数である。 $C^{ \pm}$はき裂上下面の境界であり，「はき裂面 を除いた領域の境界である。き裂面上で摩擦力がありき 裂面上での積分が 0 とはならないため積分経路はき裂面 上下 $C^{ \pm}$と任意の経路 $\Gamma$ の両方を含んだ $\Gamma \cap C^{ \pm}$となる. $s$ は「と $C^{ \pm}$上の公称表面力であり, $\boldsymbol{u}$ は変位である.

$\mathrm{E}$ 積分の值は, 有限要素解析において基準状態の，き 裂長さ $l$モデル（以後, 基本モデルと呼ぶ）と，き裂 長さが直進ないし折れ曲がり $\Delta l$ 伸びたモデル（以後，き 裂進展モデルと呼ぶ) の 2 つのモデルについて解析を行 い，き裂長さ $l$ による偏微分項は 2 点差分近似すること により，また経路積分は，表面力と変位をそれぞれ離散
化した等価節点表面力 $\boldsymbol{s}_{i}$ と節点変位 $\boldsymbol{u}_{i}$ を, 積分経路上 の全節点で和をとることにより求める.すなわち, 式 (1) の数値解析には, 次式を用いた.

$$
\begin{array}{r}
E=\sum_{i=1}^{n}\left\{\frac{s_{i}(l+\Delta l) \cdot u_{i}(l+\Delta l)-s_{i}(l) \cdot u_{i}(l)}{2 \Delta l}\right. \\
\left.-\frac{s_{i}(l+\Delta l)-s_{i}(l)}{\Delta l} \cdot u_{i}(l)\right\}
\end{array}
$$

ここで $n$ は積分経路上の節点の数であり, $\Delta l$ は基本モデ ルとき裂進展モデルのき裂長さの差である。 また式 (2) 中の変数の $(l)$ および $(l+\Delta l)$ は，それぞれ基本モデル， き裂進展モデルの物理量であることを表している.

進展き裂面上の状態は圧縮応力の大きさやその載荷履 歴などにより，さまざまな状態が考えられるが，ここで はその状態を，固着接触状態，滑り接触状態，開き状態 の 3 つに大きくわけて考える。ただし，滑り接触状態の とき, 滑り方向とは逆向きに摩擦力が発生するが, 摩擦 力は Coulomb の摩擦法則に従うものとし, そのときの 摩擦係数 $\mu$ は定数とする.

ここに，固着接触状態とは，進展き裂面上での法線方 向表面力成分が圧縮状態にあり, かつ接線方向表面力成 分が限界摩擦力以下のときである。滑り接触状態とは, 外力の負荷により進展き裂面上での接線方向表面力成分 が限界摩擦力以上になったときであり，開き状態とは， 負荷後の変形によっても接触しない状態をいい, 負荷前 に接触していた点の法線方向表面力成分が引張になる条 件となるような状態である.

\section{5 結果と考察}

\section{$5 \cdot 1$ 最大荷重值と載荷角度との関係}

Figs. 7,8 にそれぞれの初期き裂長さにおける，最大 荷重値と載荷角度 $\beta$ の関係を示す．本来ならば，き裂が 進展する瞬間時の荷重值を破壞荷重值として議論するべ きであるが，荷重の測定間隔は 1 秒でであるのに対して， 前述のようにき裂進展速度は $1 / 4000$ 秒以下であり, 厳

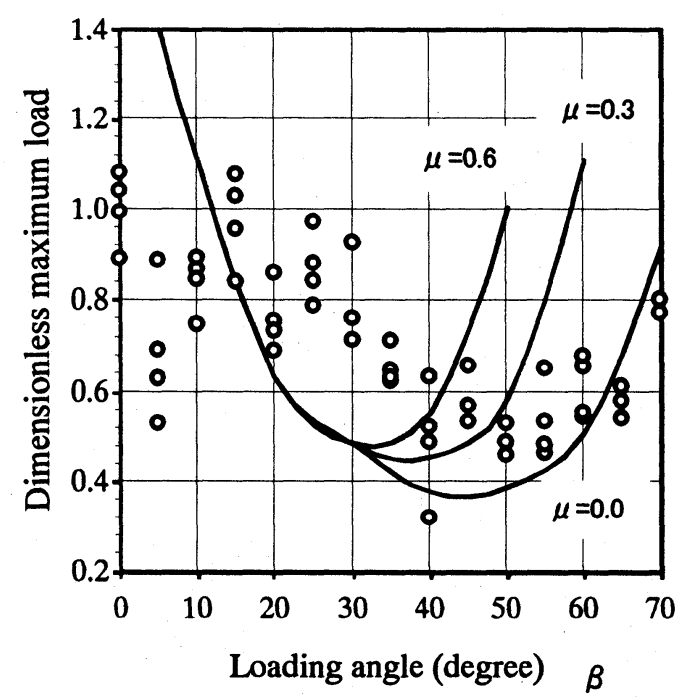

Fig. 7. Relationship between maximum load and the loading angle $; 2 \mathrm{a}=2 \mathrm{~cm}(2 \mathrm{a} / 2 \mathrm{R}=0.2)$. 


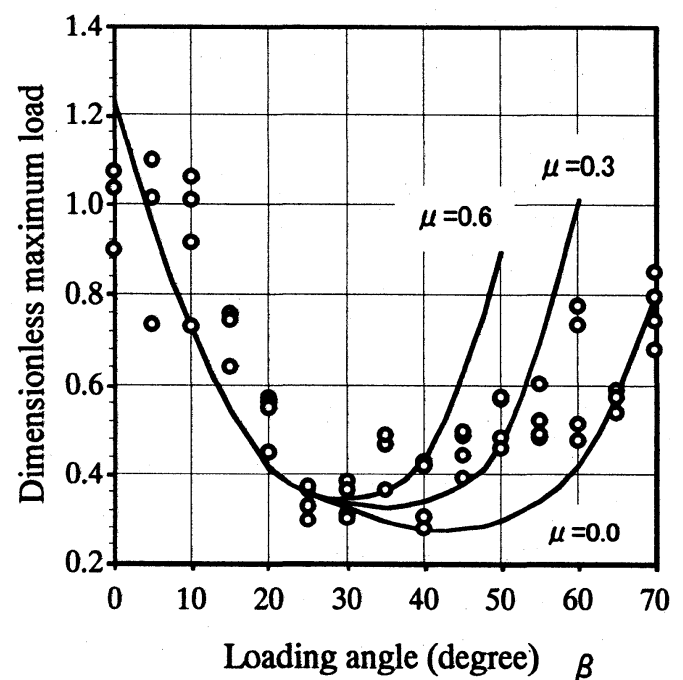

Fig. 8. Relationship between maximum load and the loading angle $; 2 \mathrm{a}=3 \mathrm{~cm}(2 \mathrm{a} / 2 \mathrm{R}=0.3)$.

密な破壊荷重值の測定が困難である。そのため，測定に おける最大荷重值が破壊荷重値に相当するものと仮定し て考察する. Figs. 7, 8 において, 縦軸の最大荷重值は 各載荷角度における最大荷重値を, 載荷角度 $0^{\circ}$ におけ る最大荷重值の平均て除して無次元化し, 弾性体の場合, エネルギ解放率とき裂進展時の荷重值の 2 乗が比例する ことから, 無次元化した值を 2 乗してある. 図中に示し た曲線については後述する。

Fig. 7 より初期き裂長さが短い場合には, 初期き裂を 供試体中央に挿入することの困難さ, 荷重値の変化が小 さいことなどによって実験值のばらつきが大きいが, 載 荷角度が $0^{\circ}$ から大きくなるに従い最大荷重値は減少し, 載荷角度がある值を超えると再び増大する傾向があるこ とがわかる. 初期き裂長さが大きい $3 \mathrm{~cm}$ の場合では, こ の傾向がより明確になり, 最大荷重値が載荷角度に対し て極小值を持つことが確認できる.

載荷角度が 00 の場合には完全なモードＩの状態であ り，初期き裂は直進進展する。載荷角度が大きくなると， き裂面内にせん断力が生じ，モードＩとモードIIの混合 モード下となり，初期き裂先端は折れ曲がり進展する。 載荷角度が小さい場合は，き裂面は開いているが，載荷 角度がさらに大きくなると, き裂面が閉じ摩擦が生じ初 期き裂先端が進展しにくくなり, 最大荷重値が再び増加 すると考えられる.

Fig. 9 にき裂長さと直径の比 $2 \mathrm{a} / 2 \mathrm{R}=0.2$, Fig. 10 に $2 \mathrm{a} / 2 \mathrm{R}=0.3$ に打けるエネルギ解放率の解析結果を示す. き裂面における摩擦係数 $\mu$ は $0.0,0.3$ 扎よび 0.6 とした。 ここに縦軸は, 載荷角度を一定とし, 折机曲がり角度を 変えて E 積分によりエネルギ解放率を解析した結果から, エネルギ解放率が最大となったき裂折れ曲がり角度にお ける解析結果を取り出し, その值を無限板内にある長さ $2 \mathrm{a}$ のき裂に, 一様応力 $\mathrm{P} /(\mathrm{R} \pi)$ が載荷された場合の理論 解 ${ }^{8}$ で除して無次元化した值である.

Figs. 9, 10 から, 載荷角度が約 $30^{\circ}$ までは，き裂面に おける摩擦係数の大ささにはあまり影響なく, 載荷角度

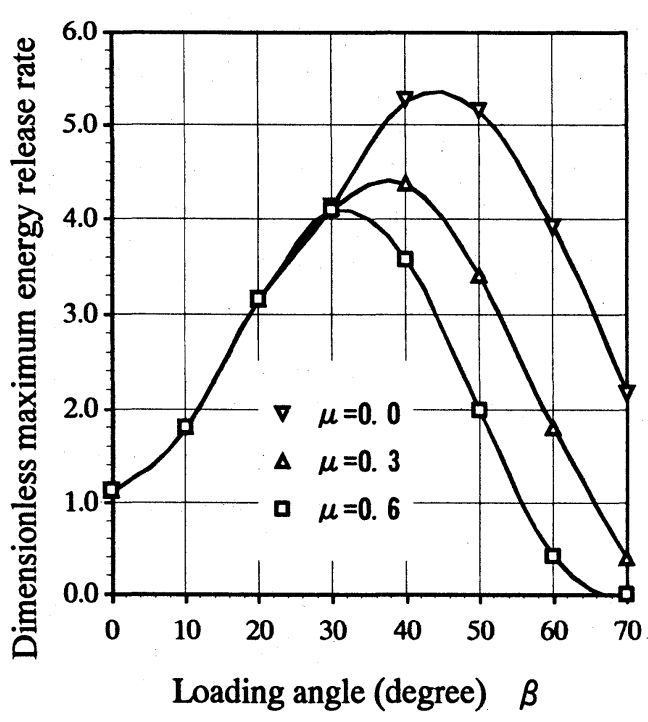

Fig. 9. Relationship between the energy release rate and the loading angle $; 2 \mathrm{a} / 2 \mathrm{R}=0.2$.

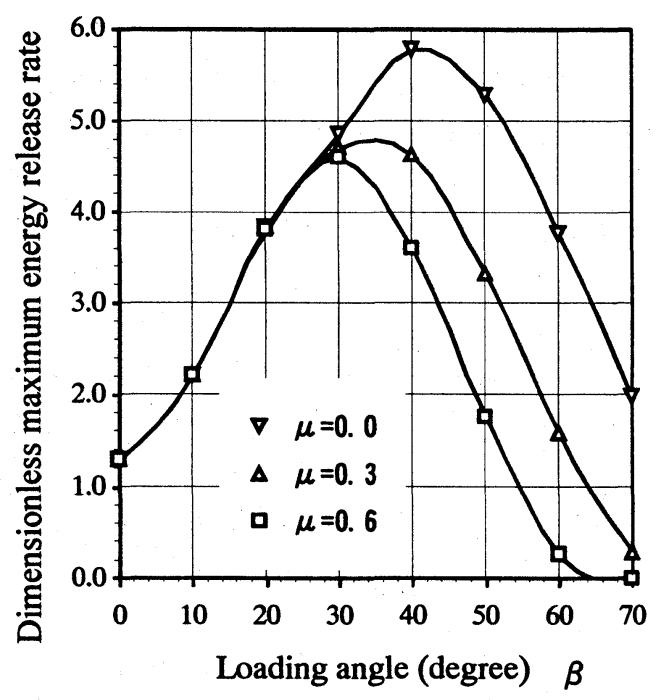

Fig. 10. Relationship between the energy release rate and the loading angle $; 2 \mathrm{a} / 2 \mathrm{R}=0.3$.

が大きくなるとともにエネルギ解放率は増大している. 載荷角度が $30^{\circ}$ を越えると, 摩擦係数 $\mu=0.0$ の場合に はさらに増大し， 40 〜 50 で最大となるが, 摩擦がある 場合には摩擦係数が大きいほどエネルギ解放率は小さく なり, $\mu=0.3$ では $30 \sim 40^{\circ}$ で, $\mu=0.6$ ではほぼ $30^{\circ}$ で 最大となる，以上のことを換言すれば，エネルギ解放率 は載荷角度に対して極大值を持ち，その極大值は，摩擦 係数が小さいほざ，大きな值であり載荷角度が大きいと きに生じていることになる。

き裂の進展がエネルギ解放率破壊規準によるものとす れば，エネルギ解放率が最大となるき裂先端が，エネル ギ解放率が最大となる方向に進展する。したがって，工 ネルギ解放率が大きくなると, き裂が進展しやすくなり, 混合モード下における破壊荷重は小さくなり，逆にエネ ルギ解放率が小さければ，き裂は進展しにくくなり，破 壊荷重は大きくなると考えられる。この理由で, Figs. 7, 8 で載荷角度に対して最大荷重が極小值を持つことと, 
Figs. 9, 10 でエネルギ解放率が極大值を持つことは対応 づけられ，混合モード下のき裂進展を破壊力学的に説明 することができる.

Figs. 7, 8 の極小值の位置と, Figs. 9,10 の極大値の 位置を比較すると, $2 \mathrm{a}=2 \mathrm{~cm}$ では $\mu=0.0$ の場合で $\beta \fallingdotseq$ $50^{\circ}, 2 \mathrm{a}=3 \mathrm{~cm}$ では $\mu=0.6$ の場合で $\beta \fallingdotseq 30^{\circ}$ で両者が比 較的よく一致している。これは，初期き裂は，元の作成 上最初約 $0.275 \mathrm{~mm}$ の幅を持っており, 圧縮荷重がかか ってもき裂長さが短い時には $\beta$ が $40 \sim 50^{\circ}$ になってもき 裂が完全に閉じなかった可能性があり，き裂が長い場合 には $\beta$ が $30^{\circ}$ 前後で閉じ摩擦効果が大きく生じたと考え られる。

さて，ここで破壊荷重値とエネルギ解放率の関係を理 論的に検討すれば，次のことが言える。実験において， 供試体寸法打よびき裂長さが一定であれば，エネルギ解 放率は, 荷重値 $P$ と載荷角度 $\beta$ の関数と考えることがで る。ここで，線形弾性体に集中荷重 $P$ が作用する場合， エネルギ解放率は $P$ の 2 乗に比例する。したがって，載 荷角度 $\beta$ のとき，エネルギ解放率 $G$ は，

$$
G=G(P, \beta)=P^{2} f(\beta)
$$

と表すことができる。ここに, $f(\beta)$ は載荷角度がエネル キ解放率に寄与する成分を表す関数である。したがって, 載荷角度 $0^{\circ}$ のときのエネルギ解放率は

$$
G_{0}=G(P, 0)=P^{2} f(0)
$$

となる，破壊荷重 $P_{c}$ で，き裂が進展したときのエネルギ 解放率は，

$$
G_{c}=G\left(P_{c}, \beta\right)=P_{c}^{2} f(\beta)
$$

となる.ここで, 式 (3) と式 (4)の比は次式で示されるよ

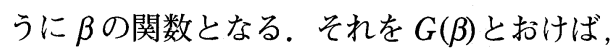

$$
G(\beta)=G / G_{0}=f(\beta) / f(0)
$$

となる.ここに, $G(\beta)$ は Fig. 9 および Fig. 10 で示され るエネルギ解放率から求めることができる。式 (5) および 式 (6)から

$$
P_{c}^{2}=G_{c} / f(\beta)=G_{c} /(G(\beta) f(0))
$$

となり，破壊荷重が載荷角度で異なることになる， $f(0)$ は一定であるから，材料の破壊勒性值 $G_{c}$ が一定である とすれば,

$$
P_{c}^{2}=C / G(\beta)
$$

の関係が得られる.ここに $C$ は定数である.

このように，エネルギ解放率に極大值が存在すれば， 破壊荷重に極小值が存在することが線形弾性体では理由 付けられる。ここに定数 $C$ は, 実験条件が変われば異な る値となる. Fig. 7 および Fig. 8 に示してある曲線は, Fig. 9 および Fig. 10 に打けるエネルギ解放率を $G(\beta)$ と

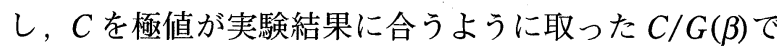
ある。

実験結果のばらつきの少ない Fig. 8 で実験值と曲線を 比較すると摩擦の影響がない載荷角度 $\beta$ が $30^{\circ}$ までは両 者はよく一致し， $\beta$ が $40^{\circ}$ 以降では，載荷角度に対する 実験值と解析值の傾向は一致しており，混合モード荷重
下におけるき裂進展挙動をエネルギ解放率による破壊規 準で検討することが妥当であることがわかる.

ただし， $\beta$ が $40^{\circ}$ 以降では, 実験值は摩擦係数が小さ い曲線と一致している，載荷角度が大きくなれば，き裂 面における摩擦が大きくなりき裂は進展し難くなり, 破 壊荷重が大きくなるものと考元られ，Fig. 8 とは矛盾す る.この理由としては, 実験条件と解析条件との違いが 考えられる. 解析では初期き裂は完全に閉じた状態とし ているが，実験ではPET を挿入して初期き裂を作成した ため，その先端が閉じて抢らず，載荷角度が大きい場合 にはき裂が折れ曲がって進展することから，この影響が 実験值に及ぼされたこと, 次に, 解析では線形弾性体と 仮定しているが，七メントペーストは完全な線形弾性体 とはみなされないこと，また，破壊荷重值として測定し た最大荷重値としたことなどが挙げられる。実験方法お よび解析方法の改善を試み，き裂面における摩擦の影響 を明らかにすることは今後の課題としたい.

\section{$5 \cdot 2$ き裂折れ曲がり角度と載荷角度との関係}

次に, 初期き裂先端のき裂折れ曲がり角度 $\theta$ の測定值 と $\mathrm{E}$ 積分による解析結果からエネルギ解放率が最大とな つた方向の比較を $2 \mathrm{a}=2 \mathrm{~cm}(2 \mathrm{a} / 2 \mathrm{R}=0.2)$ について Fig. 11 に, $2 \mathrm{a}=3 \mathrm{~cm}(2 \mathrm{a} / 2 \mathrm{R}=0.3)$ について Fig. 12 に示す. 解析結果の 3 本の曲線は, き裂面における摩擦係数の違 いによるものである. 解析結果より, き裂折れ曲がり角 度は載荷角度が大きくなると共に増大し, 載荷角度が $30^{\circ}$ を過ぎるとほぼ $70^{\circ}$ の一定の值となり, き裂面に打 ける摩擦が大きい場合には載荷角度が $60^{\circ}$ を越えるとき 裂折れ曲がり角度は小さくなることがわかる。

供試体におけるき裂折れ曲がり角度の測定は，破壊後 の供試体に打ける表裏の 4 つの初期き裂先端をマイクロ スコープ（キーエンス VH-7000）を用いて 25 倍に拡大し た画像上で行ない, 厹の平均值を取った。供試体表面で の測定であるためバラッキはかなりある． $2 \mathrm{a}=2 \mathrm{~cm}, 2 \mathrm{a}$ $=3 \mathrm{~cm}$ ともに載荷角度が $40^{\circ}$ までは解析結果より小さ目 の值であり, それ以上では解析結果をまたいで分布して

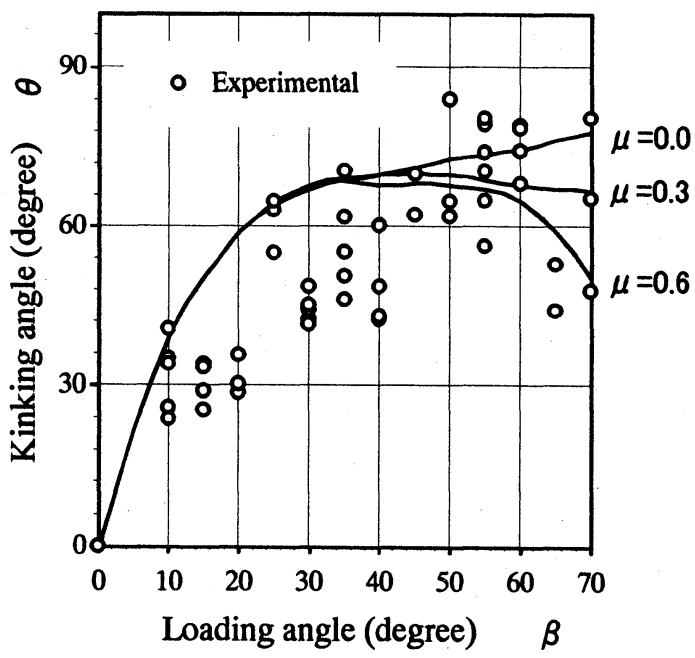

Fig. 11. Relationship between the kinking angle and the loading angle ; $2 \mathrm{a}=2 \mathrm{~cm}$. 


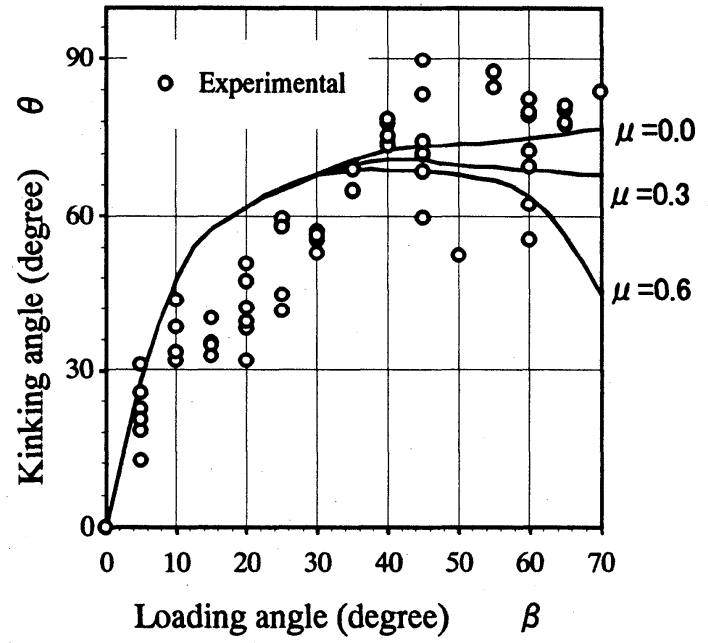

Fig. 12. Relationship between the kinking angle and the loading angle; $2 \mathrm{a}=3 \mathrm{~cm}$.

いる.しかし, 載荷角度が大きくなるに伴い, 折れ曲が り角度が大きくなっており, 解析結果と同様な傾向を示 していることがわかる.

\section{6 結}

言

本研究では, 混合モード下にあるき裂進展挙動を把握 するために，セメントペーストを用いた円盤型供試体に よる圧縮実験の結果と $\mathrm{E}$ 積分によるエネルギ解放率の解 析結果を比較検討した。 その結果明らかとなったことは 以下のとおりである.

(1) 本研究で行った夹験条件では, 初期き裂先端から 1 次き裂が発生し, その後 2 次き裂が生じる.このこと は高速度ビデオカメラの映像を画像処理することによっ て確認した。

(2) 画像解析からき裂進展挙動を確認するには差画像 を取ることがよい。

（3）実験による最大荷重は載荷角度に対して極小值を 持つ. すなわち, 摩擦係数によって異なるがき裂面に対
して載荷角度が $30^{\circ}$ から $50^{\circ}$ のときが最大荷重值が小さ く初期き裂が進展しやすい。このことは，エネルギ解放 率の解析結果が載荷角度に対して極大值を持つことで破 壊力学的にも説明できた。

（4）き裂折れ曲がり角度の測定值は，エネルギ解放率 による解析結果と概ね一致する.

ぜい性材料中に初期き裂を挿入することはかなり困難 である. 本研究で実験に用いたセメントペーストは練り 混ぜ直後は流動体で初期き裂となる PET を挿入しやす く，硬化するまでにある程度の時間がありその間にPET の位置の修正が行なえ, 硬化後はぜい性的な性質を示す。

しかし，セメントペーストでは，金属などのように， 疲労き裂によって真のき裂をつくることが難しい. 将来, より㛜密な試験を行なうことを今後の課題としたい.

本研究を行なうにあたり, 高速度ビデオカメラを貸し ていただいた福井県工業技術センター関係各位に覀心よ り感謝し，厚く御礼するしだいである.

\section{参 考 文 献}

1) A. A. Griffith, Phyl. Trans. Roy. Soc., London, A221, 163, (1921).

2) A. A. Griffith, Proc. 1st. Int. Cong. Appl. Mech., Delft, 55 (1924).

3 ) G. R. Irwin, J. Appl. Mech., 24, 361 (1957).

4 ）矢富盟祥, 䲐 洋一, 土木学会論文集 No.612/ I-46, 251 (1999).

$5)$ C. Yatomi, Int. J of Solid Structure, 19, 183 (1983).

6) 例えば小林昭一, 材料, 20,164 (1971).

7 ) 橋本堅一, 矢富盟祥, 石田 啓, 土木学会論文集, No, 513/I-31, 17 (1995).

8 ) D. P. Rooke and D. J. Cartwright, Compendium of Stress Intensity Factors, Her Majesty's Stationery Office, 228 (1974). 